\title{
Chapter 15 \\ Climatic and Environmental Limiting \\ Factors in the Mongol Empire's \\ Westward Expansion: Exploring Causes \\ for the Mongol Withdrawal \\ from Hungary in 1242
}

\section{Stephen Pow}

\begin{abstract}
From its formation in the early years of the thirteenth century, the Mongol Empire expanded rapidly along the steppe belt and trade routes comprising the Silk Road, forming partnerships with merchants and encouraging commerce, while also subjugating the resident nomadic and sedentary societies. In 1241-1242, the Mongols invaded and occupied Hungary for a year before mysteriously withdrawing eastward into the steppes. Many theories have been offered for this event and why Hungary's border ended up marking the westernmost terminus of the Mongol Empire, including most recently Büntgen and Di Cosmo's "environmental hypothesis" that short-term climatic fluctuation and environmental factors played a decisive role. This paper employs a comparative historical methodology to discuss three broad topics: the suitability of the Kingdom of Hungary for long-term occupation by the Mongols; the role that the climatic events of 1242 played in the famine that ravaged the kingdom after the withdrawal; and the role that environmental factors could have played in Mongol military setbacks and problems during the invasion. By doing so, this paper also aims to address additional points newly raised by Büntgen and Di Cosmo in a reply they made to an earlier article which questioned the enviromental hypothesis.
\end{abstract}

Keywords Mongol Empire $\cdot$ Mongol invasion of Hungary Mongol invasion of Europe $\cdot$ Climate history $\cdot$ Steppe history Kingdom of Hungary

\footnotetext{
S. Pow $(\bowtie)$

Medieval Studies, Central European University, Budapest Nador u. 9, 1051, Hungary

e-mail: Pow_Stephen@phd.ceu.edu

L. E. Yang et al. (eds.), Socio-Environmental Dynamics along the Historical Silk Road, https://doi.org/10.1007/978-3-030-00728-7_15
} 


\subsection{Introduction}

\subsubsection{Background}

The Mongol invasion of Europe in 1241-1242, centered on Hungary, appears to have been part of a major operation aimed at the permanent occupation and conquest of territories. We cannot dismiss easily the "conquest" aspect of this massive westward drive and temporary occupation of Hungary when we consider a wide range of primary sources which emphasize that such an intention existed, before and after the invasion, including texts written in thirteenth-century Mongol imperial courts (De Rachewiltz 2015, 194; Boyle 1971, 108; Jahn 1977, 53). Moreover, other regions invaded during the Mongols' larger overall campaign (1236-1244) were incorporated into their Empire. These include the Bulgar state on the Volga, the Russian principalities, and the Cuman-Kipchak tribes based on the steppe belt north of the Caspian and Black Sea. As those conquests were taking place, another smaller Mongol force was pushing westward, albeit on the southern side of the Caucasus, bringing into submission states such as Cilician Armenia, and even invading Syria by 1244 (Jackson 2005, 74-75). Thus, it is evident that the larger campaign which terminated in western Hungary and Croatia-also ruled by the king of Hungary in the thirteenth century - was one that resulted in permanent conquests and the expansion of the Mongol Empire. Yet, Hungary escaped the fate of its neighbors to the east specifically because the Mongol occupiers completely and suddenly pulled out of Europe. This is surprising for several reasons. The first is that textual accounts of the invasion of Hungary, whether from a European or Asian perspective, agree that it was a highly destructive invasion; some add it resulted in huge amounts of plunder for the withdrawing invaders (Bak and Rady 2010, 221; Boyle 1958, 271). Furthermore, the Mongols were victorious in the decisive Battle of Muhi in April 1241, which largely destroyed the Hungarian royal army, hindering the kingdom from offering further unified resistance. Recent archaeological findings, such as coin-hoards and rural settlement sites with traces of destruction, which can be positively dated to the invasion period (Fig. 15.1), bear witness to widespread destruction, particularly on the Great Hungarian Plain (Vargha 2015; Laszlovszky 2012; Laszlovszky et al. 2016). The invasion and occupation of Hungary reads like a litany of Mongol successes at the expense of the local populations and their leaders, which makes the Mongol decision to abruptly withdraw thousands of kilometers eastward in 1242 all the more mysterious to scholars. The Mongol Empire expanded over much of the Asian continent, subduing China, Korea, the Abbasid Caliphate, and the peoples of Inner Asia. Yet, no persuasive reason for the withdrawal from Hungary is actually found in the source material, and the reasons for it are an ongoing topic of research and speculation. 


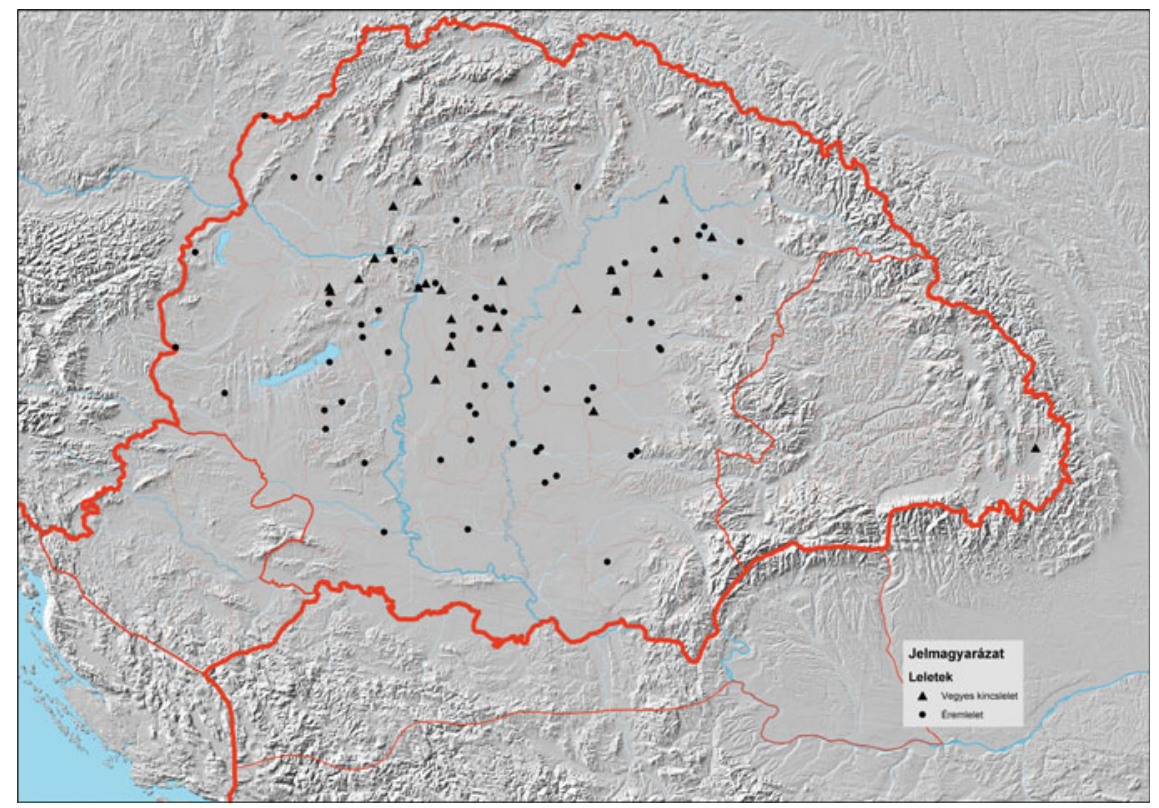

Fig. 15.1 Distribution of hoards found in Hungary connected to the invasion: triangle $=$ mixed coin and jewelry hoard; circle $=$ coin hoard. Image courtesy of the Hungarian National Museum

\subsubsection{State of the Art and Research Questions}

Regarding this invasion and withdrawal, many theories have been offered over the last century though none has reached a consensus. A "single satisfying explanation" has not emerged in the literature, Greg S. Rogers noted over two decades ago (Rogers 1996). His article was a seminal piece as it attempted to organize and categorize theories for the Mongol withdrawal in 1242, noting both the evidence for and against the various theories. He broadly defined four types of explanation for the withdrawal, which he termed: the "political" theory, the "geographical" theory, the "military weakness" theory, and the "gradual conquest" theory. The political theory, which still tends to be largely favored in literature, rests mainly on the testimony of John of Plano Carpini who visited Mongolia as a papal emissary a few years after the withdrawal. He reported that the Mongols were essentially forced by custom to take part in the election of a new khan in Mongolia, following the death of Ögödei Khan in December 1241. Yet, this seems unlikely because the Mongol leader Batu and his forces did not actually return to Mongolia (Thackston 1999, 354). He instead based his moving court on the Volga River and established the Golden Horde without ever returning for the new khan's election. The geographical theory, first suggested by Denis Sinor several decades ago, offered an alternative-the Mongols met with insufficient pasturage on the Hungarian Plain to conduct their campaigns (Sinor 1972). Joseph Fletcher disagreed with the underlying premise that the Mongols would only try to permanently occupy locations that were geographically suitable 
(Fletcher 1986), while other scholars, like Vernadsky, had argued previously that Hungary was an ideal location at the end of the steppe belt to serve as a base for operations against Europe (Rogers 1996). The military weakness theory, holding that the Mongols were too weakened to continue their conquest, has some support in primary sources but could be criticized in light of the fact that the Mongols conquered so many other great powers like the Jin Dynasty. Besides, nationalistic feeling could drive scholars to support it. Lastly, the theory of the "gradual conquest" held that conquest in 1242 might not have been the intention. This explanation has proven harder to criticize, possibly because the Mongols were good at keeping intentions and plans secret, even from the eager gaze of later historians. But a major problem with it is that our best textual source on the Mongol invasion, that of a churchman, Rogerius, who was taken prisoner during the occupation, points out that the Mongols set up a highly effective administration in Hungary during their occupation. Rogerius was even taking part in the administrators' regular meetings (Bak and Rady 2010, 209). Creating a local government seems a rather surprising act to be undertaken by a raiding party during a punitive expedition.

As noted, while none of the past explanations for the Mongol withdrawal has been wholly persuasive, theories posited more recently continue at least basically along the same tracks outlined in the article of Rogers. Peter Jackson, taking a broader view of the entire progress of Mongol-European relations from the early thirteenth century to the beginning of the fifteenth century, introduced an alarmingly complex picture of their interactions, which hardly ended in 1242 (Jackson 2005). Hungarian scholarship, as well, has not remained silent on the issue of the Mongol occupation, later invasions, and the significance and intentions behind Mongol activities directed the Kingdom of Hungary (Nagy 2003). The work of Jenő Szúcs, for instance, explored the short-term and long-term impacts of the Mongol attacks, noting that many developments once thought to represent direct responses to the Mongols had precedents; the Mongol attacks acted more as catalysts for modernizing developments while the startling recovery of the Kingdom of Hungary suggests the destruction inflicted during the first invasion of the Mongols was far from total (Szúcs 1993). I offered my own theory, the only monograph-length study on this topic, several years ago; taking a comparative approach with other Mongol conquests in diverse regions over the thirteenth century, and the long-term character of Hungary's interaction with Mongols in the aftermath of the withdrawal, I concluded that it was likely strategic problems, or future military problems perceived by the Mongol leaders, which prompted the withdrawal (Pow 2012). While this does not subscribe exactly to the "military weakness" theory as the evidence does not suggest the Mongols ever lost their capability to effectively wage war in Europe before or after 1242-I rather contend the Mongol leadership felt it was too costly or risky to advance or stay put-it still might best be placed under that rubric.

Recently, Büntgen and Di Cosmo proposed a novel combination of paleoclimatic data with documentary evidence to reach an explanation. The results of their findings formed the basis of their "environmental hypothesis" which ascribes the Mongol withdrawal in 1242 to "a general syndrome in which the effectiveness of nomadic armies was constrained by a short-term, regional-scale climate fluctuation." With dendroclimatological evidence, they were able to reconstruct a weather situation in 
Hungary, which saw above-average temperatures from 1238-1241 followed by a sudden fluctuation to unusually cold and rainy conditions in early 1242 . Owing in part to landscape and soil conditions, "marshy terrain across the Hungarian plain most likely reduced pastureland and decreased mobility" for the Mongols, bringing about their withdrawal (Büntgen and Di Cosmo 2016).

The 2016 article attracted a great deal of international media attention soon after its publication, with the findings being discussed in ordinary news stories and popular scientific websites, often announcing the resolution of a centuries-old historical mystery. Nicola Di Cosmo clarified that the climate may have been one of several factors at play; climate being the major driver behind the Mongol withdrawal did not preclude other factors playing a role. Nonetheless, he compared the weather's role in Batu's campaign in Hungary with the Russian winter's effect on Napoleon's disastrous campaign in 1812, asserting that to ignore it is "like saying the winter in Russia had no effect on Napoleon's army" (Gearin 2016).

Scholars in Hungary from a variety of disciplines, including archaeology and landscape ecology, raised questions regarding the environmental hypothesis, stemming from paleoclimatic, archaeological, and historical evidence of the invasion, and we collaborated on a response (Pinke et al. 2017b). Büntgen and Di Cosmo's investigation of the relationship between reconstructed weather patterns and documentary evidence was justified; climate exerted important effects on steppe-based societies and polities. Yet, the evidence could have led to an opposite conclusion than that reached by the authors - namely, that there is little evidence that climate was a major factor in the Mongol decision to withdraw. Our paper focused on specific aspects of their arguments that are relevant for the larger questions we are looking at, regarding Mongol involvement in the Eastern Europe region. We argued that above-average rainfalls should have been beneficial for pasturage. Besides textual evidence, coin hoards suggest the greatest Mongol impact was in the low-lying Great Hungarian Plain-where such evidence should be limited if flooding had seriously impeded Mongol mobility during their occupation (Nagy 2015; Székely 2014; Laszlovszky et al. 2016). The historical documents from the time seem virtually silent on climate issues specifically working against the Mongols. When faced with the range of data, our article concluded that the Mongol withdrawal in 1242 likely was not primarily the result of environmental and climatic drivers. Simultaneously to the publication of our work, Büntgen and Di Cosmo published a further brief reply, offering responses to five main arguments we made, while reiterating the importance of focusing on the very specific set of data and circumstances pertaining to 1242 when assessing the withdrawal (Büntgen and Di Cosmo 2017).

\subsection{Methodology}

\subsubsection{A Comparative Historical Approach}

Rather than being a simple response, point by point, to the reply of Büntgen and Di Cosmo, the intention here is to move to somewhat broader issues related to the 
historiography of the Mongol invasion of Hungary, which have been highlighted in these latest stages of the ongoing debate on the causes of the withdrawal. This does not represent a collaborative effort with specialists of various fields, but rather an individual attempt to show what the particular problems with climatic explanations are when a historian applies a broad comparative approach to the source material (Pow 2012). One of the advantages for a researcher of the Mongol Empire is the huge range of sources, diffuse in both the sense of genre and the geographical and social contexts from which they emerged.

My approach then to addressing any issue pertaining to the Mongol Empire, and in this case the role of climatic and environmental problems in the withdrawal of 1242 , is not to squander the opportunity for a wide-ranging comparison of evidence, particularly textual evidence. If the report of a Chinese emissary (Olbricht and Pinks 1980, 53), the account of a Persian governor in the service of the Mongols (Boyle 1958, 92), and a Hungarian clergyman (Bak and Rady 2010, 213) match closely in their description of the use of massed groups of local prisoners to besiege towns, for example, we should see historicity in these accounts rather than finding another explanation for the parallels. Repeatedly, historians of this period can employ comparative approaches; we can see discussions of the same events from authors in societies that had extremely limited contact with one another. Their common interface was with Mongol rulers or invaders. Often accounts from the period can be confused or cursory, but the ability to view the same events from a variety of angles is something that should be the envy of historians dealing with any other medieval topic. For a particularly relevant example, we should consider the Battle of Muhi between the Mongols and the Hungarians, in which we have a Chinese account based on Mongolian sources (the only such detailed medieval account of a battle in Europe), Persian, Hungarian, German accounts, etc. (Laszlovszky et al. 2016; Pow and Liao 2018).

In their reply article, Büntgen and Di Cosmo emphasize the importance of using "absolutely dated and spatially explicit natural archives and historical sources, when linking climate variability with human history" (Büntgen and Di Cosmo 2017). They then offer replies on five points we made: (1) We cited a letter in which Béla IV reported to the pope that his kingdom was ideally suited to the Mongols raising their herds, but the authors responded that this would be only under normal conditions, quite unlike those in 1242; (2) We pointed out that precipitation was beneficial for agricultural production in Hungary based on twentieth-century records, but the authors suggested that applies to ordinary steppe conditions but not thirteenth-century Hungary in which rising water levels would have reduced land suitable for occupation and agriculture; (3) We suggested the famine was largely manmade, but the authors held that (long-term) cold and wet conditions were found to contribute to famine in the fourteenth century; (4) We pointed out that destruction was concentrated mostly on the Great Hungarian Plain, but the authors held that weather accounted for western Hungary escaping largely intact since it was invaded only in 1242 ; (5) We showed an Early Modern depiction of Székesfehérvár to show that it was ordinarily surrounded by marshes, but the authors stated this was anachronistic and furthermore supported the view that marshes would have hindered the Mongols (Büntgen and Di Cosmo 2017). 
As is evident from the back-and-forth, the authors found our approach reliant on anachronistic data and failing to contextualize within the narrow framework of spring 1242 in the Carpathian Basin with its short-term climate situation. Here, I want to restate that an advantage Mongol historiography offers by allowing comparison of so many accounts is that we can use the broader context to make better sense of short-term events at the local level. In the following discussions, I would like to highlight three broad topics. The first is the question of Hungary's suitability for Mongol occupation, which ultimately draws into focus point (1) of Büntgen and Di Cosmo's reply. The second discussion is focused on the famine experienced during the invasion and its aftermath, which raises issues pertaining to points (2) and (3). Finally, I discuss the topic of Mongol military capacity and the issue of resistance, fortifications etc., which highlights points (4) and (5) made by the authors in their reply.

\subsection{Discussions}

\subsubsection{The Question of Hungary's "Suitability" Within the Mongol Empire: Before and After the Withdrawal of 1242}

There are two realities of Hungary's conditions, which would have made its long-term incorporation into the Mongol Empire during the thirteenth century unsurprising. The first is that the Carpathian Basin, the region in which the Kingdom of Hungary was established, is widely recognized as the westernmost extension of the long Eurasian steppe belt, stretching like a highway all the way from Mongolia in the east. Indeed, the steppe did see the rapid movement and migration of nomadic or semi-nomadic peoples along this highway, and Hungary's history before the Mongol invasion attests to no shortage of peoples such as the Huns, Avars, Pechenegs, and eventually the Magyars themselves who arrived in the ninth century and established their state in the Carpathian Basin (Pinke et al. 2017b). As such, many groups of steppic origins had viewed the area as a suitable base to migrate, raise their herds, and wage wars of conquest or simple plundering on surrounding states. Thus, we might expect that the Mongols in the thirteenth century would have viewed it in a similar way.

The second reality of medieval Hungary's conditions was that it lay on important trade routes, along which widespread international trade was carried out. Hungary had remained in the Middle Ages, after the arrival of the Magyars and the establishment of their kingdom, very much a country at the intersection of Turkic nomads, Byzantium, and the Latin West; not surprisingly, it had a highly heterogeneous population (Berend 2001, 23). The kingdom hosted significant Jewish and Muslim populations whose merchants carried on a lively international trade between Europe and Asia in the leadup to the Mongol invasion. Recent archaeological research has revealed that a series of former Roman earthwork fortifications known as the Devil's Dykes (Ördög árok or Csörsz árka) began to function as a north-south trade route 
with Muslim communities in the period of the Arpad Dynasty (1000-1301). This is evinced, for instance, by the even spacing of towns, which suggests major mercantile activity. Products such as salt would have moved along this route from Transylvania to the waterways of the Balkans and Byzantium (Pinke et al. 2017a). When we consider its active trade and political connections with Turkic nomads, Russian principalities, and Byzantium, along with its close links with the Middle East-Muslim accounts describe Hungarian Muslim clerics who went to study in Aleppo, for instance (Berend 2001, 238-239) — we can see that Hungary was very much tied into a larger Eurasian network. Friar Julian for instance ultimately reached Magna Hungaria on the Volga by moving with merchants along eastern trade networks stretching from Hungary (Göckenjan and Sweeney 1985, 75-77). From the tenth century, it was part of this trade network and its direction of emphasis was both eastward toward Kiev, a major center of international trade, and southward toward Constantinople; if not located on the routes that characterized the Silk Road per se, Hungary was at least an important extension of periphery networks in the period leading up to the Mongol invasion, though at that point Hungary's trade focus was shifting westward (Szende 2011, 168-169). These networks continued to function as major trade routes across East-Central Europe during Hungary's post-invasion period of recovery and prosperity in the fourteenth and fifteenth centuries (Fig. 15.2).

This is meaningful because the Mongol Empire, since its inception in 1206, had expanded not simply along the steppe belt, but also along the trade routes that traditionally, or perhaps out of modern fashion, are called the Silk Road. These routes shaped the empire's functions, becoming arteries of communication vital for the central government in Mongolia to exercise control over disparate regions as the empire grew. As such, we might view the Silk Road, along with the Eurasian steppe belt, as social and environmental conditions which made the Mongol nomads' unprecedented conquests possible. Chinggis Khan and his descendants had an established pattern of forming close partnerships with merchants who functioned in their empire as go-betweens and even spies (Allsen 1989). ${ }^{1}$ Merchants were some of the great beneficiaries from the conquests in the thirteenth century; we might think of Marco Polo's own storied career as a merchant simultaneously operating as an agent of the Mongol administration. When the Mongols reached Europe in the early 1240s, it seems that Hungary, sitting at the nexus of trade routes between multiple regions (Szilágyi 2012, 77-95), would have fit well within the larger framework of their empire.

Whether the Mongols were, as many scholars believe, really driven by a mandate set by Chinggis Khan for world conquest (Jackson 2006), or were simply motivated by opportunism to seize areas suitable for the conditions of their nomadic lifestyle and which offered wealth they could accumulate from commerce along trade routes

\footnotetext{
${ }^{1}$ As Thomas Allsen notes, the Turkic term for merchants in the Mongol Empire, ortoy, means "partner." Chinggis Khan had a very positive attitude to both commerce and merchants in his empire. He was using them as messengers, go-betweens, and spies, in his very first moves toward imperial expansion beyond the steppes of Mongolia. An increasing appetite for luxury items coming from the empire's frontiers only further intensified the role of merchants within it, along with the Mongol government's efforts to foster trade.
} 


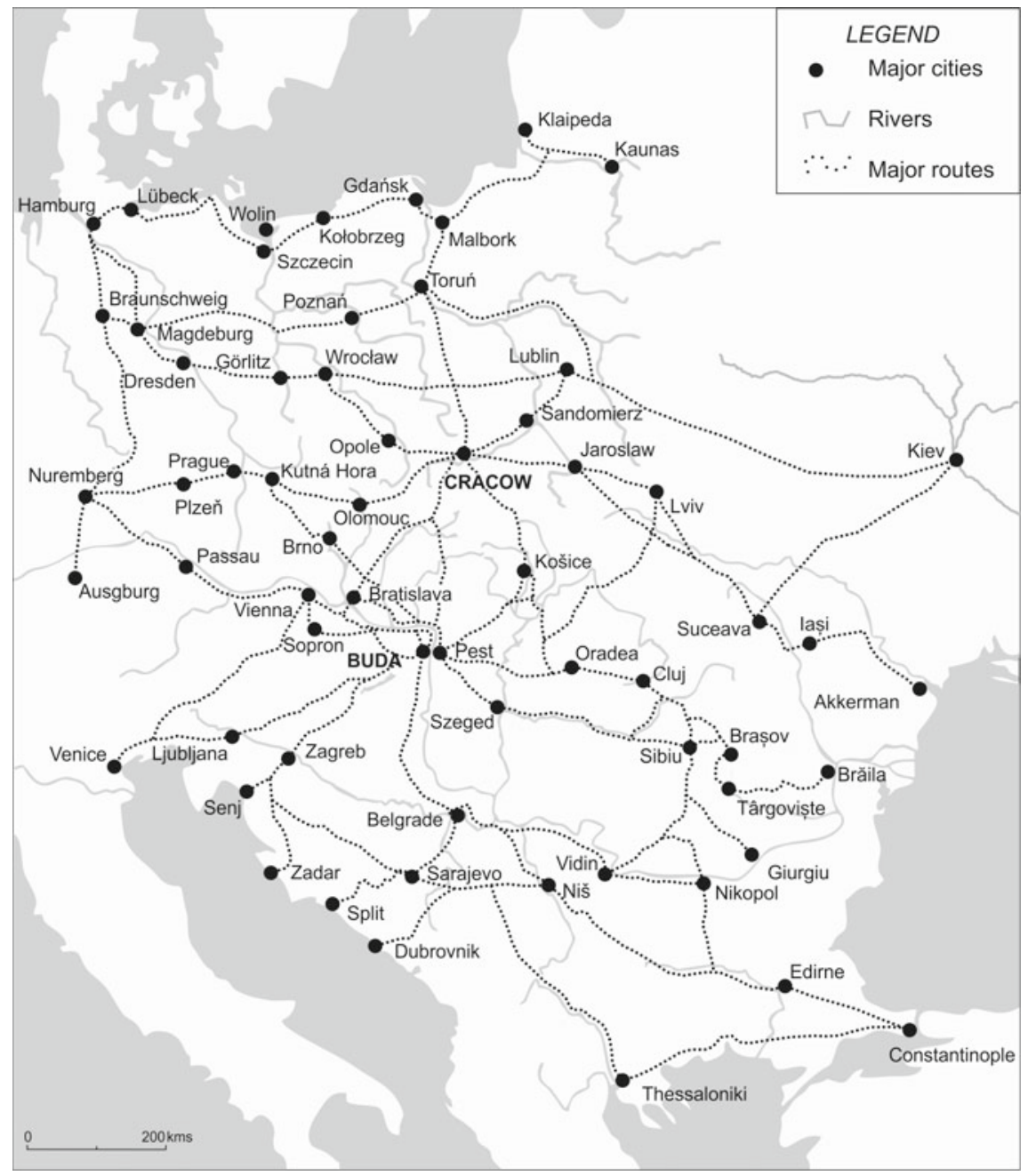

Fig. 15.2 Kraków and Buda in the road network of medieval Europe, in: On Common Path. Budapest and Kraków in the Middle Ages. Ed. Judit Benda, Virág Kiss, Grazyna Lihonczak-Nurek, Károly Magyar. Budapest: BTM, 2016, pp. 31-37. Image courtesy of András Vadas

(Berend 2001, 35), the occupation of Hungary would appear to be the next logical step in their expansion after they arrived on its borders. If we see trade routes comprising the so-called Silk Road and the Eurasian steppe belt as limiting factors to the Mongol Empire's expansion, Hungary still seems like it was suitable for a long-term 
occupation. That is what makes the Mongols' evacuation of the country in 1242, and their apparent lack of efforts to quickly return there, ${ }^{2}$ such a mystery.

If we consider that Hungary was suited for Mongol conquest and thus was occupied, there are a couple of observations related to general problems with the Büntgen and Di Cosmo's premise. First, it is difficult to imagine that such a short-term fluctuation in climate as that in early 1242 could convince a highly successful and campaign-hardened army to retreat. To subscribe to the "environmental hypothesis," one must be of the belief that a few short months of unseasonable precipitation and lower than average temperatures were the deciding factor in driving off an army of Mongols that had successfully conquered, or was to conquer, the territory from the eastern edges of Asia to Hungary. It is hard to believe that the warriors capable of conquering the steppes and forests from Mongolia to Hungary would have found the latter's climate and mud an insurmountable obstacle. That relates to a second point. The Mongols, and the other Inner Asian tribal groups they subjugated, emerged from rugged regions prone to climatic extremes far worse than what might be expected in the European continental climate of Hungary. Simply taken at face value, it is difficult to accept - to paraphrase Fletcher when he criticized Sinor's geographical theory - that people who had emerged from (and adapted a lifestyle to) such conditions, and who waged victorious wars of conquest in the forest zone of Russia, the rice paddies of Song China, and the deserts of the entire Middle East, decided to retreat from the Great Plain of Hungary because an unusually wet and cold early spring in 1242 proved too much for them (Fletcher 1986). Several historians have argued that ecological factors did come into play in some Mongol withdrawals-for instance, they withdrew from Syria in 1244 and two contemporary Near Eastern authors mentioned that the Mongols' horses' hooves were damaged by the summer heat (Jackson 2005, 74). John Masson Smith Jr. thoroughly analyzed several unsuccessful Mongol campaigns in Syria and noted that logistical factors, such as the limited supplies of pasturage and water, could have greatly constricted Mongol military operations (Smith 1984). So, there is evidence that ecological factors really did hamper the effectiveness of Mongol campaigns, but these failures seem related to long-term, ordinary conditions of regions, like the deserts of Syria. Moreover, the Mongols seem to have ultimately adapted to conditions and subjugated many powerful adversaries, such as the Song Chinese or the Abbasid Caliphate, in geographical regions that were hardly suited to steppe modes of living and fighting. It is a trend that we acknowledge their high adaptability in cases where they conquered, but in cases where they did not ultimately succeed, the conclusion is often that this was predominantly because the Mongols could not adapt to local ecological conditions.

Turning to Béla IV's letter to the pope, discussed in point (1) of Büntgen and Di Cosmo's reply and written a few years after the invasion, the king certainly was not of the mind that the Mongols deemed his country unsuitable for occupation. He thought that the Mongols were going to return, and he was hearing reports of it from his spies and contacts to the east. Moreover, he was emphatic about the danger of the

\footnotetext{
${ }^{2}$ They did, however, invade Hungary in force again in 1285 , an important detail which is neglected in the environmental hypothesis.
} 
Mongols occupying the country, in his words, "because they can settle their families and animals - in which they abound - marvelously well here, better than elsewhere" (Rosenwein 2013, 421). The authors in their reply stated that the Hungarian king was referring to normal conditions, rather than the short-term climate fluctuation of 1242. A problem is that is not what the source records. Béla did not offer any nuance to the circumstances in which the Mongols could settle.

Denis Sinor's own earlier geographic theory for the Mongol withdrawal highlights a danger related to any environmental explanation. The author is forced to overlook textual evidence that challenges a theory or amend it to make it work when faced with new data. In the original iteration of his theory Sinor recorded that the Great Hungarian Plain had an area of $100,000 \mathrm{~km}^{2}$, each horse needed 120 acres per year (based on American horse breeding statistics), each Mongol soldier needed 3 horses, and therefore Hungary could have accommodated at most 68,640 Mongol troops (Sinor 1972). A few decades later, his calculation read as follows: The Great Hungarian Plain had $42,000 \mathrm{~km}^{2}$ of pasturage, each horse needed 25 acres per year, and therefore Hungary could support only 83,027 Mongol troops because each soldier needed 5 horses (Sinor 1999). It seems like what had priority in Sinor's view was the theory and the data could be shifted around at will simply to keep the maximum number of Mongols low.

Büntgen and Di Cosmo offer something more convincing since their theory is based on a reliable paleoclimatic model, rather than a mysteriously evolving calculation, but sometimes they follow Sinor's track by making reaching inferences to connect statements in the textual primary sources to what had been observed from the reconstructed year-by-year weather conditions. An especially noticeable example of this tendency is when the authors refer to Mongol activities and decisions during the summer and fall of 1241 while they were occupying Hungary. They ordered servants to provide shelter and fodder for their horses, did not burn crops, and kept peasants alive with the command to take in the harvest. Even when the authors accede that the documentary sources are silent on any weather-related issues during that phase of the invasion, they note, "These preparations are somehow indicative of an early onset of the fall/winter in 1241" (Büntgen and Di Cosmo 2016). Statements like this leave one with the feeling that the documentary evidence is being forced to construct a narrative that emerged initially from paleoclimatic data.

Subscribing to any geographic or climatic theory requires the researcher to overlook what happened in the long-term aftermath of 1242. The Mongols regularly threatened Hungary's monarch with ultimatums to submit to their rule, and even offered him military alliances, in the years following their departure (Göckenjan 1991, 61). Büntgen and Di Cosmo did not draw really any attention to this ongoing pattern of Mongol-Hungarian interactions in formulating their hypothesis for the withdrawal. Furthermore, the Mongols did eventually launch a large-scale invasion of Hungary in 1285. Again, the motivations of the Mongols and the scale of that invasion are uncertain and subject to debate. Nonetheless, we may conclude that it was a much larger undertaking than the scant secondary literature on it would suggest. While English-language literature has not yet offered major studies on the so-called Second Mongol Invasion in 1285, two major Hungarian studies have explored these 
important, if largely overlooked, events (Székely 1988; Szőcs 2010). These works offer important perspectives from which to approach the question of what Mongol intentions were for Hungary in light of their return. Moreover, the source material does indicate the Mongols suffered in 1285 from epidemics, serious weather issues, and ultimately famine in their disorganized retreat from Hungary. That the paltry sources for the 1285 campaign so persistently mention these issues, but the larger body of sources on 1242 are utterly silent on any such difficulties suggests that the Mongol forces did not experience such problems in the earlier campaign.

Hungary's landscape and geography lent itself to nomadic incursions and occupations. This makes the fact that Hungary retained its autonomy more remarkable than the Kingdom of Bohemia's survival, for instance, or that of the principalities of Poland. As for Hungary's other regional neighbors, such as Serbia, the Kingdom of Bulgaria, and areas of present-day Romania, they actually were subjugated by the Mongols to varying degrees and for different periods during the course of the thirteenth century (Vásáry 2005, 69-94). ${ }^{3}$ Though Büntgen and Di Cosmo do acknowledge that shortly after evacuating Hungary, the Mongols invaded and subjugated Bulgaria, they do not really mention the larger trend of Mongol conquest and interference in the Balkans throughout the remainder of the thirteenth century. In fact, they state, "Our paper shows that a possible reason why the Mongols who occupied Russia under Batu and his successors did not make further attempts to expand westward may have depended on the realization that local conditions would not have supported a prolonged occupation" (Büntgen and Di Cosmo 2016).

\subsubsection{The Issue of the 1242-1243 Famine in Hungary and Its Causes}

The famine that affected the Kingdom of Hungary during and after the Mongol invasion is a frequently discussed topic among Hungarian researchers of the Middle Ages. Andrea Kiss, for instance, has looked at the topic and while she argued that the Mongol invasion was "very much responsible for the hunger," she also speculated that the unusual cold of the winter of 1241-1242, coupled with abundant snow and ice, may have played a contributing role in the situation (Kiss 2000). As such, this could support Büntgen and Di Cosmo's hypothesis. On the other hand, József Laszlovszky has pointed out in a publication touching on economic history that the ecological situation of medieval Hungary was such that famine occurred very rarely-which would suggest the famine in the 1240s was brought on by a truly exceptional set of circumstances, i.e. severe disruption caused by the invasion (Laszlovszky et al. 2018). In any case, it should be noted that this famine has been already heavily studied by generations of Hungarian scholars. The most recent conclusions by Andrea Kiss are that during major and long-lasting climatic changes and many years of extreme

\footnotetext{
${ }^{3}$ Vásáry's work offers a long and detailed summary of the continual Mongol conquests and interference in the Balkans throughout the second half of the thirteenth century.
} 
weather, famine occurred but very rarely in the whole country. Famines and food shortage crises in Hungary were usually related to particular regions. There were very few exceptional cases when such situations affected the whole kingdom (e.g. the mid-1310s, 1362, or 1364). But even in these periods different social groups were affected in different ways and there were areas which were lightly or negligibly affected. It is also important to underline that the crisis periods were the same as those faced in contemporary Western or Central European contexts - that is, people in other regions of Europe were experiencing the same famine (Kiss et al. 2016).

While the causes of the famine in 1242 remain an ongoing topic of debate, the issue has much significance for the question of the withdrawal, since much of the textual evidence being used to support a climatic explanation relates to famine. A major component of Büntgen and Di Cosmo's theory is their attempt to relate the famine to a food crisis that the Mongol occupiers were experiencing. They argue that the Mongol decision to feed their prisoners with less desirable parts of sheep, as recorded by their captive Rogerius, indicates that the Mongols themselves could foresee the great famine that was to overtake Hungary. Deciding to feed prisoners only parts of sheep, rather than the whole sheep they were receiving beforehand, could be motivated by a variety of factors, including a lost sense of the value or importance of the prisoners. Indeed, Rogerius heard from informants that the same prisoners would be subjected to a wholesale massacre (Bak and Rady 2010, 221). Moreover, Rogerius, who escaped captivity around that time, mentioned that this change in the rations allotted to prisoners happened only after the Mongols began withdrawing from eastern Hungary into Cumania (Wallachia and/or Moldavia). So, it seems rather problematic to try to link the Mongol decision to feed prisoners less generously with a recognition that famine was going to strike Hungary.

Famine did severely afflict the local Hungarian population, but textual sources make it clear why this happened, and climate was not the primary driver. A contemporary churchman stated that it happened because the peasants were forced during the invasion to abandon their crop fields for two growing seasons (Karbic et al. 2006, 303). Naturally, if the farmers were unable to cultivate crops because they could not stay on their fields owing to the disruption and danger of the invasion, a serious famine was going to set in. Others had harvested some crops but only to supply them to the Mongols in 1241 (Bak and Rady 2010, 211).

What happened in Hungary in 1242 was hardly an isolated incident. Shortly after the withdrawal, a Dominican emissary was sent into the Mongol Empire to meet them with letters from the pope. He passed through many regions that had been affected recently by invasions and eventually met with the Mongols in Armenia. In his report, detailing Mongol methods of waging war, he stated, "In every country which the Tartars destroy, famine always follows" (Richard 1965, 44). What his report would suggest is that Mongol invasions consistently triggered famine in all the affected areas, far beyond Hungary, and we can easily infer that this happened because it was a larger strategy of the Mongols. The famines they triggered were intentional-a sort of weapon to crush resistance. When we consider that testimony, it is very hard to entertain the notion that the starvation which affected Hungary's people in 1242 was the result of a short-term fluctuation in climate. Kirakos of Gandzak, an Armenian 
churchman taken prisoner, noted that the Mongols invaded in the summer when the harvest had not been reaped or gathered in the granaries. They came with their livestock and ate and trampled everything, so that when they left Armenia in the winter the people had nothing to eat and died of starvation. However, Kirakos noted, that winter was "not severely cold, as at other times but as mild as one could wish" (Bedrosian 1986, 224). Here we see a close parallel to what happened in Hungary in terms of famine, albeit without the cold weather.

If we need further proof, Juvaini describes instigating famine as a regular feature of steppe warfare against sedentary societies. Describing the actions of Küchlüg, a Naiman chieftain who fled from Chinggis Khan to the Qara Qitai and was attempting to subjugate the famous Silk Road city of Kashgar, Juvaini noted, "Küchlüg, at every harvest time, would send his troops to devour their crops and consume them with fire. When for three or four years they had been prevented from gathering in their corn, and a great dearth had made its appearance, and the populace were distressed with famine; they then submitted to his command" (Boyle 1958, 65). This type of warfare was being practiced from the very beginning of the empire, even by refugees fleeing from Chinggis Khan. Changchun, a Chinese Daoist monk, passed through the former Khwarazm Empire shortly after its conquest and described a society so broken down by famine and brigandage that the Mongol governor of Samarkand refused to reside in the palace of the former shah (Waley 1931, 93). In their campaigns against Korea, the Mongols inflicted famine on the population to pressure the king to submit. The king in turn complained to the Mongol leadership in terms that sound rather familiar: "... several times you sent army leaders to censure [the people]. The people have no land to cultivate and in farming there was no time to harvest. Considering this land [had only] flowering grass, what could be produced? Thinking that we had no way of offering up tribute and to present it would be difficult, my fear was extreme" (Schultz and Kang 2014, 307). The Mongols inflicted such severe starvation on the population that finally they started killing their own government-appointed leaders or inciting Mongols to attack certain fortresses. Ultimately the military governor of Korea was overthrown and assassinated, not long after he refused to open a granary. In the end, the king finally sent his son to the Mongol court to submit in 1259 by which time the Mongols had seized the entire harvest, epidemics were breaking out, and starvation was rampant (Schultz and Kang 2014, 369-377).

A comparative look at texts from different times and regions should lead us to the conclusion that the famine that unfolded was intentionally brought about by the invaders. As for the Mongols' animals and their pasturage needs, the carrying capacity of the Great Hungarian Plain allowed for millions of animals, even during the Little Ice Age of the Early Modern era (Pinke et al. 2017b), so it is difficult to imagine that even a large Mongol army would have faced a crisis with pasturage owing to shortterm climate fluctuations. Büntgen and Di Cosmo did not always clearly distinguish if the food crisis was one afflicting the animals of the Mongol occupiers or simply one affecting the agrarian-based populace of Hungary. These are two very different things. Furthermore, it seems the authors supplied documentary evidence of a victual crisis facing the latter group as evidence that the former group was experiencing something similar. It is problematic to link the accounts of widespread starvation of Hungary's 
sedentary, agrarian population to the issue of pasturage being limited by short-term climate fluctuation of early 1242 . The obvious problem with such a viewpoint is that it is well known that the Mongols relied primarily on their herds of animals for food. So, the disruption of grain harvests would not have had the same effect on the Mongol occupiers as it had on the local peasantry. Büntgen and Di Cosmo, however, argued that not only did cold wet conditions in 1242 affect cultivated crop production, but they limited pasturage in the Great Plain, placing stresses on the Mongols to feed their animals. The sources from a Hungarian context, and far beyond, leave us no doubt that the famine was mostly a manmade and intentionally triggered phenomenon.

\subsubsection{Local Resistance and the Possibility of Diminished Military Capacity as a Result of Climate in 1242}

There are primary source accounts of military problems that the Mongols experienced in 1242, and it is an important question to what degree these were caused by a wet and cold climate and its effect on soil, fortifications, pasturage etc. In point (4) of their reply, Büntgen and Di Cosmo suggested a sort of dichotomy between the military successes experienced by the Mongols in 1241, and the setbacks they are recorded to have suffered, ostensibly because of climate, in 1242 (Büntgen and Di Cosmo 2017). Nonetheless, their description of 1241 as a year flush with successes might be a bit of an oversimplification because the Mongols appear to have been prevented from crossing the Danube and pursuing the Hungarian king, Béla IV. In fact, the king stated in his letter to the pope that his forces held off the Mongols from advancing for ten months after the disaster at Muhi (Rosenwein 2013, 421). Furthermore, the biography of Sübe'etei, the famous general who oversaw the invasion of Hungary, which is found in the Yuan Shi, states that the Mongol princes wanted to flee the country during or shortly after the battle of Muhi in April 1241 (Pow and Liao 2018). They were only prevented from doing so by Sübe'etei shaming them. All of this suggests that the level of resistance they were experiencing may have had a demoralizing effect on the Mongol commanders already a year before they in fact withdrew their forces.

Büntgen and Di Cosmo suggest that the difficulties the Mongols experienced taking fortresses in 1242 had much to do with the swampy conditions they encountered, owing to the unique climate situation experienced at that time. This tends to reductionism since it ignores some topographical differences (between the hilly west and flat east of Hungary for instance), and the archaeological issues related to fortifications. In fact, an earlier study by Erik Fügedi demonstrated that the important factors in the survival of fortresses during the invasion had to do with building materials to a large degree; stone castles fared much better than wood and earthworks. However, another key element, perhaps more important than building materials, was the strategic situation of the fortress on a hilltop or island (Fügedi 1986, 45-48, 57-59). Those based on hilltops (Pannonhalma, Esztergom's citadel, Klis fortress in Croatia), 
or islands (Tihany, Trogir, Wroclaw) stand out for their successful resistance against concerted Mongol attacks. Particularly in Croatia where Béla IV had taken refuge, Mongol sieges mentioned in the sources usually ended abortively (Karbic et al. 2006, 299-301). If conditions in the flatlands and plains were indeed swampy from heavy precipitation, it is difficult to imagine that the outcome of Mongol sieges of hilltops or offshore islands like Trogir were seriously altered by the short-term climate fluctuation in the winter and spring of 1241-1242. The Mongols probably experienced more or less ordinary conditions in those sieges, so the cause of unsuccessful outcomes should probably be attached to the strong strategic position and natural or manmade defenses of these places rather than to weather. In response to Büntgen and Di Cosmo's criticism in point (5) of their reply-that a sixteenth-century depiction of Székesfevehérvár is anachronistic_- I contend that the image was chosen to highlight the fact that many fortresses and towns were highly defensible in ordinary conditions. The eastern flatlands and plains, however, that should have been protected by swampy conditions in early 1242, according to Büntgen and Di Cosmo's hypothesis, are the very areas that show the greatest signs of devastation and destruction at the hands of the invaders (Laszlovszky 2012). Moreover, new archaeological investigations in those same areas of the Great Hungarian Plain reveal a number of large improvised settlements fortified by ditches and earthworks, where people from the surrounding area came for defense. In all cases, they show signs of being overrun and destroyed which suggests such improvised fortifications in the open plain were simply not effective at resisting the Mongols (Laszlovszky et al. 2018). The findings closely parallel the account of Rogerius of the situation that unfolded at places like Pereg, where people from seventy villages gathered and held out against Mongol onslaughts for a week before being overrun (Bak and Rady 2010, 213).

Previously, I looked at Mongol sieges of fortresses and urban centers in Russia, China, ${ }^{4}$ Korea, India, Persian, the Caucasus, etc. A wide geographical and chronological framework was useful because it demonstrated that well-situated fortresses and those built of stone tended to perform well against Mongol assaults in different geographical regions (Pow 2012, 79-121). Thus, in making sense of failed Mongol assaults on fortresses, a comparative approach is useful, especially when we consider that descriptions of Mongol tactics for taking fortresses show distinct patterns, regardless of the geographical origin and societal context of the authors.

Returning to the issue of Hungary in 1242, we have documentary evidence that the unusually cool winter conditions worked to the advantage of the Mongols in a decisive way on at least one occasion. The unseasonable cold froze the Danube, an unusual occurrence, which enabled the Mongols to at last cross over and continue their conquests in western Hungary. This important event also enabled them to resume their pursuit of Béla IV who had been safely based in Croatia for roughly a year after the defeat at Muhi. So, we are faced with statements in the sources that the evinced shortterm climate situation worked against the Hungarians and to the strategic benefit of

\footnotetext{
${ }^{4}$ They did conquer China, but it took many decades and only was accomplished with the aid of many Chinese defectors and supporters. Furthermore, they had great difficulty with strategically situated Song fortresses (Pow 2012).
} 
the Mongols. Using the same data with which Büntgen and Di Cosmo worked, other authors could hypothetically have reached a totally different interpretation, arguing instead that short-term climate trends worked to facilitate the Mongol occupation of Hungary. Therefore, I continue to contend, as I did earlier (Pow 2012, 73), that local resistance and a growing perception of a threatening and unresolvable military situation made the Mongol leadership decide to pull back in early 1242. As it was, however, they first moved into Bulgaria and apparently subjugated it on their way out. While strategic issues were a primary driver in my view, we must certainly be facing a very complex set of circumstances and multi-causal drivers which prompted the withdrawal, which is precisely why a single satisfying explanation has eluded researchers.

\subsection{Conclusions}

In this paper, beyond simply rehashing some issues with Büntgen and Di Cosmo's "environmental hypothesis," I hope to have offered something novel in my discussions of broader topics. First, I have attempted to demonstrate the suitability of the Kingdom of Hungary for incorporation into the Mongol Empire in the thirteenth century. By forming a segment of the same steppe belt from which the Mongols first arose and crossing a series of international trade networks of the medieval period, its appeal to the Mongols as a potential subject state must have been obvious to their leadership. In light of this, problems with Denis Sinor's geographical theory and previously undiscussed issues with Büntgen and Di Cosmo's hypothesis were raised. For instance, the viewpoint that a few months of unseasonable cold and above average precipitation convinced experienced Mongol leaders that the Carpathian Basin was unsuitable for a long-term occupation ignores the larger context of their successful and often overlooked conquests in the Balkans in subsequent years. This unfortunate tendency to isolate Hungary and the major invasion it suffered from the larger set of ongoing Mongol activity in southeastern Europe afterwards is probably detrimental to our fuller understanding of why they invaded in the first place, what they hoped to accomplish, and of course the question of the withdrawal itself. Second, I have demonstrated with a wide range of textual material that the Mongols used famine as a weapon against people they were trying to subjugate everywhere. When we combine that evidence with recent findings on medieval Hungary's reaction to long-term climate change, it seems that the famine of 1242 was largely manmade. Thus, the use of textual accounts of famine to support a climate-centered explanation for the withdrawal is untenable. Finally, this paper discussed the problem that strategically situated fortresses represented for the Mongols in any geographical context and in any climate, which is why strategic sites were selected in the first place, and why the castles that held out against the Mongols often had perennially strong natural defenses. The results of the discussions in this paper illustrate that a comparative analysis of a broad range of data, particularly textual material, is an effective methodological approach toward understanding even very specific events that occurred in the Mongol Empire's history. 
Büntgen and Di Cosmo's argument for the 1242 withdrawal posits that the wet conditions in the winter and spring made the formerly favorable situation of the Mongols suddenly problematic because soil wetness delayed the onset of vegetation, while the muddy terrain interfered with their military capability. So, the authors argue, the withdrawal in the spring took place in conditions of "(i) reduced mobility and military effectiveness; (ii) reduced fodder for the horses; and (iii) reduced victuals for the army." We can group points (ii) and (iii) together, and state that the authors hold that the wet weather had precipitated a crisis for the Mongols to feed themselves and their animals. Point (i) holds that Mongol military operations, such as sieges, were seriously impeded by this same weather situation (Büntgen and Di Cosmo 2016). But when we look at these two distinct arguments in turn, we can see the authors used some documentary evidence to support their hypothesis unpersuasively. Moreover, there is other available documentary evidence, not employed by the authors, which contradicts their viewpoint. The silence in Latin texts on any weather-related phenomena driving off the Mongols is curious, were it the case, since this would allow authors of a clerical background to assert that God had interfered with nature to spare Christendom. Rather, nature aided the Mongols at key points.

Though I have outlined some criticisms of their theory, the authors' project certainly has been beneficial for scholarship. They used climate science to reconstruct the weather in Hungary during the invasion and in the lead-up to it. This reconstruction sheds light on the conditions in the Kingdom of Hungary before the invasion and can be explored in light of political and social conditions documented in the sources. Their work provides a confirmation of the accounts of an unusually cold winter in 1241-1242 found in several sources, and their visual mapping of the withdrawal routes is more in line with what the primary sources describe than one could find previously in monographs or maps depicting the campaign. Furthermore, Büntgen and Di Cosmo's work was a necessary and useful attempt to explore the possible connections between climate and the Mongol withdrawal using the scientific methods now available. For some readers, the takeaway from Büntgen and Di Cosmo's collaborative paper is that it was a necessary and useful exercise to explore the effects of the climate on the Mongol invasion of Hungary. What that exploration ultimately suggests, however, is that we should continue to seek additional causes, rather than emphasizing short-term climate fluctuation, for the withdrawal in 1242. As a final observation, in their reply, Büntgen and Di Cosmo advised to avoid following deterministic and reductionist approaches to these issues (Büntgen and Di Cosmo 2017), a point on which I fully agree. That is why I also aim at an approach that offers a multicausal, complex interpretation of the events of the Mongol invasion and withdrawal, in which climate could have played a meaningful role.

Acknowledgements My sincere thanks to Liang E. Yang for organizing the PAGES-supported conference, "The Rise and Fall: Environmental Factors in the Socio-Cultural Changes of the Ancient Silk Road Area" held at Kiel University in September 2017. I also thank him for editing the volume and for his patience and advice on this article. I express my gratitude to Zsolt Pinke, József Laszlovszky, László Ferenczi, and Beatrix F. Romhányi for their careful feedback with the text. My thanks to Csaba Tóth of the Hungarian National Museum, Katalin Szende, András Vadas, and Balázs Nagy for their assistance with the figures. 


\section{References}

Allsen, Thomas T. (1989). Mongolian Princes and their Merchant Partners, 1200-1260. Asia Major, 2(2), 83-126.

Bak, J., \& Rady, M. (trans.). (2010). Master Roger's Epistle to the Sorrowful Lament upon the Destruction of the Kingdom of Hungary by the Tatars. Budapest: CEU Press.

Bedrosian, R. (trans.). (1986). Kirakos Gandzakets'i. History of the Armenians. New York: Sources of the Armenian Tradition.

Berend, Nora. (2001). At the Gates of Christendom. Cambridge: Cambridge University Press.

Boyle, J. A. (trans.). (1958). Genghis Khan: The History of the World Conqueror by 'Ala-ad-din 'Ata-Malik Juvaini. Manchester, UK: Manchester University Press.

Boyle, J. A. (trans.). (1971). The Successors of Genghis Khan. New York: Columbia University Press.

Büntgen, U., \& Di Cosmo, N. (2016). Climatic and environmental aspects of the Mongol withdrawal from Hungary in 1242 CE. Scientific Reports, https://doi.org/10.1038/srep25606.

Büntgen, U., \& Di Cosmo, N. (2017). Reply to Climate of doubt: a re-evaluation of Büntgen and Di Cosmo's environmental hypothesis for the Mongol withdrawal from Hungary, 1242 CE. Scientific Reports. https://doi.org/10.1038/s41598-017-12126-8.

Denis, S. (1999). The Mongols in the West. Journal of Asian History, 33(1), 1-44.

De Rachewiltz, I. (2015). The Secret History of the Mongols: A Mongolian Epic Chronicle from the Thirteenth Century, In: J. C. Street (Ed.), Madison: University of Wisconsin. Books and Monographs. Book 4.http://cedar.www.edu/cedarbooks/4.

Fletcher, J. (1986). The Mongols: Ecological and Social Perspectives. Harvard Journal of Asiatic Studies, 46, 11-50.

Fügedi, E. (1986). Castle and Society in Medieval Hungary (1000-1437). Budapest: Akadémiai Kiadó.

Gearin, C. (2016). Mongol hordes gave up on conquering Europe due to wet weather. New Scientist, May 26.

Göckenjan, H. (1991). Der Westfeldzug (1236-1242) aus mongolischer Sicht. In U. Schmilewski (ed.), Wahlstatt 1241: Beiträge zur Mongolenschlacht bei Liegntiz und zu ihre Nachwirkungen (pp. 35-76). Würzberg: Bergstadtverlag Wilhelm Gottlieb Korn.

Göckenjan, H., \& Sweeney, J. R. (1985). Der Mongolensturm: Berichte von Augenzeugen und Zeitgenossen 1235-1250. Graz: Verlag Styria.

Jackson, P. (2005). Mongols and the West. Harlow: Pearson.

Jackson, P. (2006). World-conquest and Local Accommodation: Threat and Blandishment in Mongol Diplomacy. In History and Historiography of Post-Mongol Central Asia and the Middle East: Studies in Honor of John E. Woods. In:ed. J. Pfeiffer \& S. A. Quinn, 11-15. Wiesbaden: Harrassowitz.

Jahn, Karl. (1977). Die Frankengeschichte des Rasid ad-Din. Vienna: Österreichische Akademie der Wissenschaften.

Karbić, D. et al. (trans.). (2006). Thomas of Spalato, History of the Bishops of Salona and Split. Budapest: CEU Press.

Kiss, A. (2000). Weather events during the first Tatar invasion in Hungary (1241-42). Acta Geographica Universitatis Szegediensis, 37, 149-156.

Kiss, A., Piti, F., \& Sebők, F. (2016). 14. századi rossz termések, élelmiszerhiány, drágaság, (éh)ínség - és feltételezhető okaik Magyarországon. In Magyar gazdaságtörténeti évkönyv 2016, ed. György Kövér, Ágnes Pogány, and Boglárka Weisz, 23-79. Budapest: Magyar Tudományos Akadémia Bölcsészettudományi Kutatóközpont.

Laszlovszky, J. (2012). Material Remains of the Mongolian Invasion in Hungary and Development-Led Archaeology. Hungarian Archaeology E-Journal Spring, 1-3. http://www. hungarianarchaeology.hu/wp-content/uploads/2012/06/eng_LJ_material_remains_12T.pdf. 
Laszlovszky, J., Pow, S., \& Pusztai, T. (2016). Reconstructing the battle of Muhi and the Mongol invasion of Hungary in 1241: New Archaeological and Historical Approaches. Hungarian Archaeology E-Journal Winter, 2016, 29-38.

Laszlovszky, J., Pow, S., Romhányi, B. F., Ferenczi, L., \& Pinke, Z. (2018). Contextualizing the Mongol Invasion of Hungary in 1241-42: Short- and Long-term Perspectives. Hungarian Historical Review, 7(3), 419-450.

Nagy, B. (ed.). (2003). Tatárjárás. Nemzet és emlékezet [Mongol Invasion]. Budapest: Osiris.

Nagy, B. (2015). Tatárjárás kori pénzleletek a Dél-Dunántúlról. In Fiatal Középkoros Régészek VI. Konferenciájának Tanulmánykötete, ed. Csilla Szőllősy and Krisztián Pokrovenszki, 277-285. Székesfehérvár: Szent István Király Múzeum.

Olbricht, P., \& Pinks, E. (trans.). (1980). Meng-ta pei-lu und Hei-ta shih-lüeh: Chinesische Gesandtenberichte über die Frühen Mongolen 1221 und 1237. Wiesbaden: Harrassowitz.

Pinke, Z., Benö, D., Ferenczi, L. (2017a). A Csörsz árok és egy középkori út térbeli kapcsolata. In Specimina Nova Dissertationum ex Instituto Historiae Antiquae et Archaeologicae Universitatis Quinqueecclesiensis [forthcoming].

Pinke, Z., Ferenczi, L., Romhányi, B. F., Laszlovszky, J., \& Pow, S. (2017b). Climate of doubt: a re-evaluation of Büntgen and Di Cosmo's environmental hypothesis for the Mongol withdrawal from Hungary, 1242 CE. Scientific Reports. https://doi.org/10.1038/s41598-017-12128-6. https:// www.nature.com/articles/s41598-017-12128-6.

Pow, L. S. (2012). Deep Ditches and Well-Built Walls: A Reappraisal of the Mongol Withdrawal from Europe in 1242. Master's Thesis. University of Calgary. http://theses.ucalgary.ca/handle/ $11023 / 232$.

Pow, S., \& Liao, J. (2018). Subutai: Sorting Fact from Fiction Surrounding the Mongol Empire's Greatest General (With Translations of Subutai's Two Biographies in the Yuan Shi). Journal of Chinese Military History, 7(1), 37-76.

Richard, J. (trans.). (1965). Simon of Saint-Quentin: Histoire des Tartares. Paris: Librairie orientaliste Paul Geuthner.

Rogers, G. S. (1996). An Examination of Historians' Explanations for the Mongol Withdrawal from Central Europe. East European Quarterly, 30, 3-26.

Rosenwein, B. H. (ed.). (2013). Reading the Middle Ages: Sources from Europe, Byzantium, and the Islamic World. Toronto: University of Toronto Press.

Schultz, E. J., \& Kang, H. H. W. (2014). Koryosa Choryo II: Essentials of Korean History. Seoul: Jinmoondang Publishing Company.

Sinor, D. (1972). Horse and Pasture in Inner Asian History. Oriens Extremus, 19, 171-183.

Smith Jr, J. M. (1984). Ayn Jalut: Mamluk Success or Mongol Failure?. Harvard Journal of Asiatic Studies, 44, 307-345.

Szende, K. (2011). Towns along the way: Changing patterns of long-distance trade and the urban network of medieval Hungary. In H. Houben \& K. Toomaspoeg (Eds.), Towns and Communication. Volume 2: Communication between Towns (pp. 161-226). Lecce: Mario Congedo Editore.

Székely, G. (1988). Egy elfeledett rettegés: a második tatárjárás a magyar történeti hagyományokban és az egyetemes összefüggésekben. Századok, 122, 52-88.

Székely, G. (2014). Tatárjárás és numizmatika - Egy történelmi katasztrófa pénzforgalmi aspektusai. In S. Rosta \& G. V. Székely (eds.), “Carmen miserabile” A tatárjárás magyarországi emlékei. Tanulmányok Pálóczi Horváth András 70. születésnapja tiszteletére (pp. 331-344). Kecskemét: Kecskeméti Katona József Múzeum.

Szilágyi, M. (2012). Árpád Period Communication Networks: Road Systems in Western Transdanubia. PhD thesis. Budapest: Central European University. http://goya.ceu.hu/record= b1164773 S0.

Szőcs, T. (2010). Egy második 'tatárjárás'? A tatár-magyar kapcsolatok a XIII. század második felébe. Belvedere Meridionale, 22(3-4), 16-49.

Szúcs, J. (1993). Az utolsó Árpádok [The Last Árpáds]. Budapest: MTA Történettudományi Intézete.

Thackston, W. (1999). Rashiduddin Fazlullah's Jami'u'tawarikh: Compendium of Chronicles (2nd ed.). Cambridge, MA: Harvard University Press. 
Vargha, M. (2015). Hoards, Grave Goods, Jewellery: Objects in Hoards and in Burial Contexts during the Mongol Invasion of Central Europe. Budapest: Archaeopress.

Vásáry, I. (2005). Cumans and Tatars. Cambridge: Cambridge University Press.

Waley, A. (trans.). (1931). The Travels of an Alchemist: The Journey of the Taoist Ch'ang Ch'un from China to the Hindukush at the Summons of Chingiz Khan. London: Routledge.

Open Access This chapter is licensed under the terms of the Creative Commons Attribution 4.0 International License (http://creativecommons.org/licenses/by/4.0/), which permits use, sharing, adaptation, distribution and reproduction in any medium or format, as long as you give appropriate credit to the original author(s) and the source, provide a link to the Creative Commons license and indicate if changes were made.

The images or other third party material in this chapter are included in the chapter's Creative Commons license, unless indicated otherwise in a credit line to the material. If material is not included in the chapter's Creative Commons license and your intended use is not permitted by statutory regulation or exceeds the permitted use, you will need to obtain permission directly from the copyright holder.

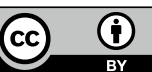

